\title{
Morphology and function of human Leydig cells in vitro. Immunocytochemical and radioimmunological analyses
}

\author{
B. Bilinska, M. Kotula-Balak, J. Sadowska \\ Department of Endocrinology and Tissue Culture, Institute of Zoology, Jagiellonian University, Krakow, \\ Poland
}

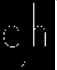

C2009 European Journal of Histochemistry

The aim of our study was to show whether the cells isolated from testes of patients underwent bilateral orchiectomy for prostatic cancer are able to grown in vitro, and if so, are functionally active. Immuncytochemistry was performed to show the functional status of human cultured cells. In detail, immunolocalization of luteinizing hormone receptors (LHR), mitochondria, and cytoskeletal elements was demonstrated. Moreover, radioimmunological assay was used to measure testosterone secretion by cultured Leydig cells. Using Nomarski interference contrast and fine immunofluorescence analysis the positive immunostaining for LHR was observed in almost all Leydig cells, however it was of various intensity in individual cells. Testosterone measurement revealed significant difference between testosterone secretion by hCG-stimulated and unstimulated Leydig cells $(p<0.05)$. Moreover, testosterone levels were significantly higher in 24- and 48hour-cultures than in those of $72 \mathrm{hrs}(p<0.05)$. Morphological analysis of Leydig cells in culture revealed the presence of mononuclear and multinucleate cells. The latter cells occurred in both hCG-stimulated and unstimulated cultures. In Leydig cells labeled with a molecular marker MitoTtracker, an abundance of mitochondria and typical distribution of microtubules and microfilaments were observed irrespective of the number of nuclei within the cell, suggesting no functional differences between mono- and multinucleate human Leydig cells in vitro. Since the percentage of multinucleate cells was similar in both hCG-stimulated and unstimulated cultures $(23.70 \%$ and $22.80 \%$ ), respectively, the appearance of these cell population seems to be independent of hormonal stimulation.

Key words: human Leydig cells, LH receptors, primary culture, hCG-stimulation, immunocytochemistry, testosterone secretion; multinucleate cells, multicolor staining.

Correspondence: Barbara Bilinska,

Institute of Zoology, Jagiellonian University,

Ingardena 6, 30-060 Kraków, Poland

Tel. +48.12663 2418 .

Fax: +48.12634 0785 .

E-mail: bbili@zuk.iz.uj.edu.pl

Paper accepted on January 26, 2009

European Journal of Histochemistry

2009; vol. 53 issue 1 (January-March): 35-42
I $\mathrm{t}$ is well established that testosterone biosynthesis depends on the existence of mature Leydig cells in the testicular interstitium. Human Leydig cells arise from mesenchymal cells or fibroblast-like precursor cells through a hormonally regulated differentiation process (Chemes, 1996). Production of testosterone in human and mammalian Leydig cells is dependent on LH stimulation in vivo and on $\mathrm{LH} / \mathrm{hCG}$ stimulation in in vitro conditions; to respond to hormonal regulation the cells are equipped with functional receptors for $\mathrm{LH}$ (Amador and Bartke, 1987; Simpson et al., 1987; Mendis-Handagama et al., 1990; Cooke, 1996; Ramadoss et al., 2006). In man, the $\Delta^{5}$-metabolic pathway is the major pathway for the metabolism of pregnenolone to testosterone (Rommerts, 1990). According to Hammar and Petersson (1986) in human testis from young and elderly men with prostatic carcinoma also the 5-ene pathway is preferred. For optimal steroidogenic function a number of neuroendocrine and neuronal markers have been demonstrated in human Leydig cells in vivo by the group of Holstein (Middendorff et al., 1993; 1995). Moreover, production of testosterone in Leydig cells, requires the presence of functionally active enzymes acting within mitochondria and the smooth endoplasmic reticulum (Payne and 0'Shaughnessy, 1996; for review see Haider, 2004).

Recent studies have shown that Leydig cells become hypofunctional with age. In the rat, aged Leydig cells produce less testosterone than Leydig cells from young adult rats (Luo et al., 1996; for review Zirkin et al., 1997). A detailed characteristics of aged rat Leydig cells in vivo, including reduced testosterone biosynthesis and reduced cell volume has been described by Ewing and Zirkin (1983). Now, there is evidence from in vitro studies that reactive oxygen species can result in the inhibition of testosterone production in mouse Leydig cells by affecting steroidogenic enzymes (Stocco et 
al. 1993; Peltola et al., 1996; Cao et al., 2004).

Considering human samples as a very rare and valuable biological material, the aim of this study was to show whether Leydig cells obtained from testes of elderly patients who underwent orchiectomy for prostatic cancer are able to grown in vitro, and if so, are functionally active. For this purpose localization of luteinizing hormone receptors ( $L H R$ ) and visualization of mitochondria and cytoskeletal elements in both hCG-stimulated and unstimulated Leydig cell cultures were performed, as well as testosterone secretion by cultured Leydig cells was measured. It is worth noting that the effect of LH and an involvement of cytoskeletal proteins in steroidogenesis of mouse Leydig cells in vitro have been demonstrated by our own (Bilinska, 1989) and mitochondria have been described as integrally involved in Leydig cell steroidogenesis (Bilinska 1994; Kotula-Balak et al., 2001).

\section{Materials and Methods}

\section{Human material}

Human testes were removed from patients $(n=4)$ undergoing bilateral orchiectomy for prostatic cancer (The Urology Clinic, Collegium Medicum, Jagiellonian University). The patients ranged in age from 60 to 67 years; they were physiologically normal. The Regional Commission of Bioethics at the Jagiellonian University approved the study; all of the patients had given their written, informed consent.

The testicular tissue was chilled immediately after surgical excision and transported on ice to the laboratory where it was set up for Leydig cell isolation and culture. All solutions were sterile and the isolation procedure was performed under aseptic conditions.

\section{Cell isolation and culture procedure}

All tissues used in this study were ascertained to be histologically normal. A piece of decapsulated testes was used for the preparation of Leydig cell suspension as described previously (Chemes et al., 1992) with a couple of modifications. Briefly, testicular tissue was carefully rinsed with fresh medium Ham's F-12/Dulbecco's Modified Eagle medium (DME; $1 / 1 ; \mathrm{v} / \mathrm{v}$ ) supplemented with $15 \mathrm{mM}$ $\mathrm{NaHCO}_{3}, 20 \mathrm{mM}$ HEPES, pH 7.4; and antibiotics (penicillin, $100 \mathrm{U} / \mathrm{mL}$; streptomycin, $10 \mu \mathrm{g} / \mathrm{mL}$; nystatin, $10 \mathrm{U} / \mathrm{mL}$ ) and gently dissected with forceps. Then, the tissue was submitted to an enzymatic digestion in the presence of $0.04 \%$ collagenase (type I, Sigma Chemical Co. St Louis MO, USA) and soybean trypsin inhibitor $(1.0 \mu \mathrm{g} / \mathrm{mL})$ in F12/DME medium, under a constant agitation at $34^{\circ} \mathrm{C}$ for $40 \mathrm{~min}$. After three decantations the supernatant was collected, filtered through a nylon gauze and centrifuged at 200x $\mathrm{g}$ for $4 \mathrm{~min}$. Then, the cell pellet was washed twice and kept in fresh F12/DME medium. Next, the second collagenase treatment was performed on residual tissue fragments and all further steps of the procedure were identical as above. Finally, suspended interstitial cells obtained from the two enzymatic digestions were purified on a 4-layer discontinuous Percoll (Pharmacia, Uppsala, Sweden) gradient 21\%, $26 \%, 34 \%$, and $60 \%$ in F-12/DME. After centrifugation, $800 \times \mathrm{g}$, for $20 \mathrm{~min}$ at $4^{\circ} \mathrm{C}$ as low temperature significantly prevents cell aggregation and then centrifugation at room temperature with lowspeed, $90 \times \mathrm{g}$ for $10 \mathrm{~min}$, the cell band between $34 \%$ and $60 \%$ Percoll containing Leydig cells was collected, washed to remove Percoll, and resuspended in Ham's F-12/DME medium (as above) supplemented additionally with $2 \%$ fetal calf serum and $10 \mu \mathrm{g} / \mathrm{mL}$ transferrin. The purity of the cells was about $80-83 \%$ as it was checked by a histochemical test for $\Delta^{5}, 3 \beta$-hydroxysteroid dehydrogenase $\left(\Delta^{5}, 3 \beta-H S D\right)$ activity. Viability of the cells assessed by trypan blue exclusion test was $<94 \%$. Purified Leydig cells $\left(0.5 \times 10^{6}\right.$ cells/well) were plated in 24-well-culture dishes (Nunc, Kalmstrup, Denmark), cultured for 48 hours at $34^{\circ} \mathrm{C}$ in a humidified atmosphere of $5 \% \mathrm{CO}_{2}$ in air. The cells were cultured with $1.25 \mathrm{IU} / \mathrm{mL}$ hCG (human chorionic gonadotropin, Pregnyl, Organon) or without during the entire culture period. The culture media were changed every other day, collected, frozen, and stored at $-20^{\circ}$ for hormone determinations. For morphology and immunocytochemistry each well was closed with a round glass coverslip of appropriate diameter (13 mm; Menzel-Glaser, Braunschweig, Germany). At the end of culture period the coverslips were removed and the Leydig cell cultures were fixed with absolute methanol and stained with May-Grünwald Giemsa (M-GG) dyes. For immunohistochemistry the cultured cells were fixed with $2 \%$ formaldehyde freshly prepared from paraformaldehyde and permeabilized with $0.1 \%$ Triton X-100 in Tris-buffered saline (TBS; 0.05 M 
Tris- $\mathrm{HCl}$ plus $0.15 \mathrm{M} \mathrm{NaCl}, \mathrm{pH}$ 7.6) as described previously (Bilinska and Litwin, 1995).

To calculate the percentage of multinucleate cells in both stimulated and unstimulated Leydig cell cultures $1 \times 100$ Leydig cells in each culture were counted. Results of 4 separate measurements for each culture were expressed as mean $\pm S D$.

\section{Immunocytochemistry}

Cultured Leydig cells were processed for the visualization of luteinizing hormone receptor (LHR) using a polyclonal rabbit antibody against LHR (1:100; BIOTREND Chemikalien GmbH, Köln, Germany) (Kopera et al., 2008). Next, biotinylated secondary antibody, goat anti-rabbit IgG (1: 500; Vector, Burlingame CA, USA) was applied. Finally, avidin-biotinylated horseradish peroxidase complex (ABC/HRP; 1:100; Dako, Glostrup, Denmark) was used. The color reaction was developed by means of Stable DAB (Research Genetics, Inc., Huntsville $A L, U S A$ ) for 3-4 min. For negative control, Leydig cell cultures were incubated in the presence of irrelevant IgGs instead of primary antibody. The cells were examined with a Leica DMR microscope (Leica Microsystems, GmBH Wetzlar, Wetzlar Germany) using Nomarski interference contrast. In some specimens fluorescein isothiocyanate (FITC)conjugated IgG (1:80; Sigma Chemical Co. St Louis MO, USA) was applied instead of biotinylated goat anti-rabbit IgG and the cells were examined with a laser confocal microscope (LSM 510 META, Axiovert 200M, ConfoCor 3; Carl Zeiss MicroImaging $\mathrm{GmbH}$, Jena Germany).

The second part of Leydig cell cultures were stained with an anti- $\beta$ tubulin rabbit polyclonal antibody (1:160; Sigma Chemical Co. St Louis MO, USA) followed by FITC-conjugated IgGs as the secondary antibody (1:80; Sigma) for labeling microtubules. Additionally, some cultures were stained with rhodaminyl-phalloidin (a gift from Professor T. Wieland, Heidelberg, Germany) for labeling F-actin and DAPI (Sigma) as one of the most widely used nuclear counterstains for nuclei. (Figure 1 0-P). For selective staining of mitochondria in living Leydig cells Mito Tracker $^{\circledR}$ Red CMXRos probe was used (Molecular Probes, Eugene OR, USA) (Kotula et al., 2001). Then, the cells were fixed, permeabilized (as above), stained with FITC-phalloidin for F-actin (Molecular Probes) and DAPI for labeling nuclei. After each step in all the procedures, cells were carefully rinsed with Tris-buffered saline (TBS; $0.05 \mathrm{M}$ Tris$\mathrm{HCl}$ plus $0.15 \mathrm{M} \mathrm{NaCl}, \mathrm{pH} 7.6$ ); antibodies were also diluted in TBS buffer.

\section{Testosterone measurement}

Leydig cell culture media were analyzed for testosterone content using radioimmunological technique as described in detail (Kotula-Balak et al., 2004b). It was determined using $\left[1,2,6,7,-{ }^{3} \mathrm{H}\right]$ testosterone (The Radiochemical Centre, Nycomed Amersham, Buckinghamshire, England), specific activity, $81.0 \mathrm{Ci} / \mathrm{mmol}$, as tracer and an antibody raised in rabbit against testosterone-3-0-carboxy methylo-oxime-bovine serum albumin (BSA). The lower limit of sensitivity of the assay was in the order of $5 \mathrm{pg} /$ tube. Coefficients of variation within and between assays were $7.2 \%$ and $9.6 \%$, respectively. All samples were assayed in duplicates from 4 separate experiments. Testosterone levels are expressed in $\mathrm{ng} / 10^{6}$ cells/24h. Statistical evaluation of the data included one-way analysis of variance (with the significance level at $p<0.05$ ) and the Duncan's multiple range test.

\section{Results}

\section{Morphology}

On the basis of light microscopic examination all Leydig cells growing in a 72-hour-monolayer system required an initial 24-h culture period to attach to the glass (Figure 1 A-B) and next $24 \mathrm{~h}$ in culture to form a monolayer (Figure $1 \mathrm{D}-\mathrm{E}$ ). Leydig cells were either epithelioid in shape with abundant cytoplasm (Figure $1 \mathrm{~B}, \mathrm{D}-\mathrm{E}$ ) or slightly elongated (Figure $1 \mathrm{~B}-\mathrm{C}, \mathrm{F}$ ). Under the influence of $\mathrm{hCG}$ Leydig cells had a more regular multilateral shape (Figure $1 \mathrm{D}-\mathrm{F}$ ). The cells from unstimulated cultures became fibroblast-like after a further culture period ( $72 \mathrm{~h}$ ). This effect was sporadically observed in hCG-stimulated cultures (Figure 1 C, F). Interestingly, multinucleate cells ranged from 2-10 nuclei occurred in both hormonally stimulated cultures and unstimulated ones (Figure 1 B-F). The percentage of multinucleate cells is given in Table 1 .

\section{Immunocytochemical analysis}

Using both Nomarski interference contrast and fine immunofluorescence analysis the positive immunostaining for LHR was localized at the cell plasma membrane level (Figure 1 G-L) of 24-and 
48-hour Leydig cell cultures. The intensity of the staining was slightly stronger in hCG-stimulated cultures than in control ones (Figure $1 \mathrm{I}-J, L$ ). Irrespective of the number of Leydig cell nuclei, multinucleate cells were also positively stained for LHR (Figure $1 \mathrm{H}, \mathrm{J}$, an insert in $\mathrm{H}$ ). By 72 hour in culture Leydig cells displayed very weak staining for LHR or were immunonegative (not shown). There was no immunostaining for LHR when the primary antibody was replaced by normal goat serum (an insert in Figure $1 \mathrm{~J}$ ). Typical distribution of microtubules (Figure $1 \mathrm{M}-\mathrm{N}$ ) and microfilaments (Figure $10-P$ ) was noticed irrespective of the number of nuclei as shown by immunofluorescence and DAPI, one of the most widely used nuclear counterstains (Figure $10-P$ ). Sporadically, in the multinucleate cells stained for microtubules, nuclei appeared to be positively stained (Figure 1 N). In Leydig cells labeled with MitoTtracker Red CMXRos an abundance of mitochondria was observed in the cell cytoplasm in both mononuclear and multinucleate cells (Figure $1 \mathrm{P}$ ).

\section{Radioimmunological analysis}

Radioimmunological analysis of testosterone levels revealed differences between testosterone secretion by hCG-stimulated and unstimulated Leydig cells. Human Leydig cells of unstimulated cultures secreted a lower amount of testosterone than Leydig cells of hCG-stimulated cultures $(p<0.05)$. Moreover, the capability of hCG-stimulated and unstimulated Leydig cells in vitro to secrete testosterone diminished during the culture period. Differences were statistically significant at $p<0.05$ level (Table 2).

\section{Discussion}

Due to the rare availability of human material, the testis of rodents has long been utilized in studies on testicular structure and biosynthesis of androgens by Leydig cells (Preslock, 1980; Mather et al., 1981; Zirkin et al., 1997; Svechnikov et al., 2001). There are several reports describing functional morphology of human Leydig cells in vivo, including studies on fetal, pre- and postpubertal testes (Nistal et al., 1986a; Makabe et al., 1995; Prince, 1990; Carreau, 1996; Chen et al., 1996). Chemes et al. (1992) isolated human Leydig cell mesenchymal precursors to show the capacity of
Table 1. The percentage of multinucleate Leydig cells in unstimulated and hCG-stimulated cultures. Data are presented as the mean \pm SD $(n=4)$.

\begin{tabular}{lccc}
\hline $\begin{array}{l}\text { 48h-Leydig cell cultures } \\
(n=4)\end{array}$ & \multicolumn{4}{c}{ Percentage of multinucleate Leydig cells } \\
& $2-4$ nuclei & $5-7$ nuclei & $8-10$ nuclei \\
\hline Unstimulated cells & $13.75 \pm 0.96$ & $6.75 \pm 0.96$ & $3.25 \pm 0.50$ \\
hCG-stimulated cells & $13.75 \pm 2.22$ & $6.50 \pm 1.29$ & $3.00 \pm 0.82$ \\
\hline
\end{tabular}

Table 2. Testosterone secretion by human Leydig cells in vitro. Data are presented as the mean $\pm \operatorname{SEM}(n=4)$. The significance level was considered to be $p<0.05$. Means with the different letters (A, B) are statistically different (hCG-stimulated versus unstimulated cultures), whereas means with the different letters $(a, b, c)$ within the row are statistically different between each of the time points of culture.

\begin{tabular}{lcll}
\hline & $\begin{array}{r}\text { Testosterone secretion by human Leydig cells in vitro } \\
{\left[n g / 10^{6} \text { cells } / 24 h \pm S E M\right]}\end{array}$ & \\
\hline Cell cultures $(n=4)$ & 24 -hour & 48 -hour & 72 -hour \\
\hline $\begin{array}{l}\text { Unstimulated cells } \\
\text { hCG-stimulated cells }\end{array}$ & $\begin{array}{l}5.76 \pm 0.66^{\mathrm{A}, \mathrm{a}} \\
9.83 \pm 1.18^{\mathrm{B}, \mathrm{a}}\end{array}$ & $\begin{array}{l}4.29 \pm 0.82^{\mathrm{A,b}} \\
6.85 \pm 1.03^{\mathrm{B}, \mathrm{b}}\end{array}$ & $0.68 \pm 0.16^{\mathrm{A,c}}$ \\
\hline
\end{tabular}

testosterone secretion and responsiveness to hCG of mesenchymal cells isolated from patients with androgen insensitivity syndrome. To date, however, there are only few data on morphology and function of human Leydig cells growing in a primary culture (Maillard et al., 1994).

In our in vitro study, using both immunocytochemistry and fine immunofluorescence analysis, the positive staining for LHR was demonstrated at the cell plasma membrane level of the 24-and 48 hour-cell cultures. Very often, the staining in individual Leydig cells of the same culture varied in its intensity that could reflect a functional heterogeneity of Leydig cells in vitro as reported previously in Leydig cells of rodent testes (Kotula-Balak et al., 2005; 2007). By 72 hours in culture Leydig cells displayed very weak staining for LHR or were immunonegative, suggesting that during culture the cells become hypofunctional. Perhaps the culture behavior could potentially reflect the in vivo situation, since it is well known that the presence of LHR is needed for a proper functioning of Leydig cells. Morphologically, hCG-stimulated cells appeared to be more regular in shape compared with the cells from unstimulated cultures. Interestingly, in Leydig cell population we observed multinucleate Leydig cells $(23,20 \%$ and $22.80 \%)$ in both hCG-stimulat- 


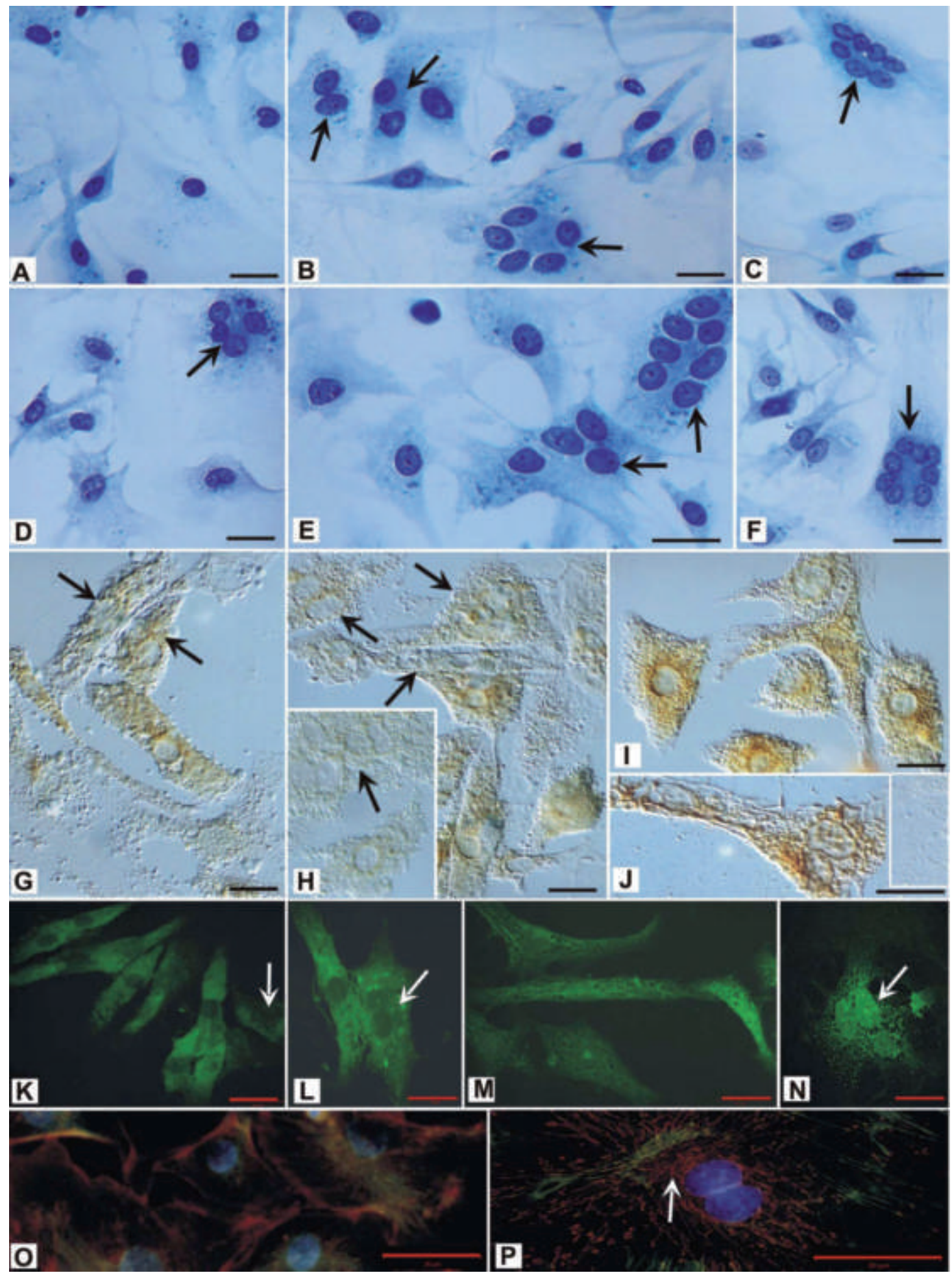

Figure 1. (A-P) Human Leydig cells in vitro. Bars $=20 \mu \mathrm{m}$. Morphology of M-GG stained Leydig cells in 24-hour-culture (A, D), 48-hour-culture (B, E), and 72-hour-culture (C, F). (A, B, C) unstimulated cultures. (D, E, F) hCG- stimulated cultures. Note the appearance of multinucleate cells in both culture conditions and during entire culture period (arrows). Immunostaining for LHR in 48-hour-old Leydig cells (GL). Using Nomarski interference contrast (G-J) and fine immunofluorescence analysis the positive staining for LHR at the cell plasma membrane level was observed (K-L). Note a stronger intensity of the staining in hCG-stimulated cells (H-J, L) compared with that of unstimulated cells (G, an insert in H, K). Irrespective of the number of Leydig cell nuclei, multinucleate cells always positively stained for LHR (arrows). No staining for LHR observed when the primary antibody was omitted (an insert in J). Typical distribution of microtubules (M-N) and microfilaments (O-P) whatever the number of nuclei. Sporadically, after hCG stimulation, nuclei were positively stained for microtubules (arrow) (N). In Leydig cells labeled with MitoTtracker Red CMXRos an abundance of mitochondria was observed (arrow) (P). 
ed and unstimulated cultures, respectively, what indicates that the formation of multinucleate cells is independent of hormonal stimulation in vitro. Multinucleate cells were found functionally active since they expressed $\mathrm{LH}$ receptors for the first two days of culture as did mononuclear Leydig cells. The existence of multinucleate Leydig cells in human testes has been a well known feature, however there are no data demonstrating the presence of multinucleate cells in culture. Schulze (1984) and Nistal et al. (1986b) described the presence of bi- or trinucleate Leydig cells as common in human testicular specimens. Using the PAP method the group of Nistal demonstrated functional activity of multinucleate Leydig cells in vivo. They reported a marked increase in the number of multinucleate Leydig cells with age, especially between the 4th to the 6th decade of life. In our study the testes were removed from elder than sixty-year-old patients, therefore it seems possible that the age of patients was a main cause of multinucleate cell appearance in vitro. Amat et al. (1986) provided ultrastructural evidence of mitosis in adult human cells suggesting that mitotic Leydig cells may contribute either to an increase in the number of Leydig cells or to the formation of multinucleate Leydig cells when karyokinesis without cytokinesis occurs. Multinuclearity of Leydig cells in vitro is difficult to discuss, however it is likely that it protects from effects of DNA damage. Multinucleate Leydig cells have also been observed in testicular disorders such as Klinefelter's syndrome and varicocele (KotulaBalak et al., 1994a; Aragona et al., 1994).

Using a fluorescent mitochondrial marker we have shown an abundance of mitochondria in Leydig cells in vitro independently of the number of cell nuclei. Numerous mitochondria indicate functionally active cells as shown in mouse Leydig cells in vitro (Bilinska 1994; Kotula-Balak et al., 2001). In earlier microscopic study at the ultrascructural level Chemes and co-workers (1992) reported that human Leydig cells possess an abundant smooth endoplasmic reticulum and steroid-type mitochondria. Of importance, Prince (1999) in his thorough study described tubulolamellar morphology of the mitochondrial cristae of human Leydig cells suggesting that the diversity of form of the cristae correlates structure and function in the process of steroidogenesis. The involvement of microtubules and microfilaments in steroidogenesis has been previously demonstrated in rodent Leydig cells in vitro
(Bilinska, 1989; Bilinska et al., 1997; 1999); therefore typical filament pattern in almost all human Leydig cells might reflect a normal functional state of the cultured cells.

Radioimmunological measurement of testosterone levels in human Leydig cells revealed a high testosterone secretion by the cells during the first 48 hour in culture. Moreover, it was significantly higher in the hCG-stimulated cultures compared with unstimulated ones, confirming several reports on the animal and human models (Simpson et al., 1987; Chemes et al., 1992; Maillard et al., 1994; Rivarola et al., 1995). After the next 24 hour in culture testosterone concentrations and the response to hCG stimulation of Leydig cells were very low, suggesting that deficits in individual Leydig cells may explain the age-related reductions in serum testosterone. This is also in agreement with earlier reports demonstrating that Leydig cells in primary culture rapidly undergo dedifferentiation (Purvis et al., 1978; Mather et al., 1981; Klinefelter and Ewing 1989; Maillard et al., 1994). However, the enhancement of long-term testosterone secretion by human Leydig cells when cocultured with human Sertoli cells has been observed by the group of Saez (Lejeune et al., 1998). According to the authors, in humans, as in other species, Sertoli cells increase Leydig cell steroidogenic activity and a gonadotrophin FSH enhances the effect of Sertoli cells on Leydig cells. Additionally, a clear-cut response of cAMP to an acute hCG stimulation has been demonstrated by this group for both Leydig cells cultured alone and co-cultured with Sertoli cells. Based on reports to date on responsiveness to $\mathrm{hCG}$ of rat and human Leydig cells in vitro it may be concluded that the function of human Leydig cells is more similar to that of the rat than thought previously.

Finally, it can be added that culture of purified cell populations in defined media is often preferred to in vivo studies for the investigation of specialized cell functions as shown in the present study.

\section{Acknowledgments}

The authors dedicate this study to Dr. Andrzej Bugajski MD., the former Head of the Urology Clinic, Collegium Medicum, Jagiellonian University. $\mathrm{H}$ is sudden and sorrowful death made our further scientific cooperation impossible. The authors are grateful to Professor Elzbieta Pyza, Director of the Division of Scanning Confocal Microscopy, 
Institute of Zoology, Jagiellonian University for providing confocal microscopy facilities (LSM 510 META, Axiovert 200M, ConfoCor 3; Carl Zeiss MicroImaging GmbH, Jena, Germany), Pawel Weber, MSc., for his expert help in photographic work with the confocal microscope, and to Dr. Anna Wojtusiak for radioimmunological assays.

\section{Funding}

This work was financially supported by the Ministry of Science and Higher Education, a grant DS/770-K/ZDS/000781.

\section{References}

Amador G, Bartke A. Actions of human chorionic gonadotropin on Leydig cell function in hamsters with photoperiod-induced testicular atrophy. Ann NY Acad Sci 1987;513:353-5.

Amat $\mathrm{P}$, Paniagua R, Nistal M, Martin A. Mitosis in adult human Leydig cells. Cell Tissue Res 1986; 243:219-21.

Aragona F, Ragazzi R, Pozzan GB, De Caro R, Munari PF, Milani C, et al. Correlation of testicular volume, histology and LHRH test in adolescents with idiopathic varicocele. Eur Urol 1994;26:61-6.

Bilinska B. Visualization of the cytoskeleton in Leydig cells in vitro. Effect of luteinizing hormone and cytoskeletal disrupting drugs. Histochemistry 1989;93:105-10.

Bilinska B. Staining with ANS fluorescent dye reveals distribution of mitochondria and lipid droplets in cultured Leydig cells. Folia Histochem Cytobiol 1994;32: 21-5.

Bilinska B, Litwin JA. Immunocytochemical demonstration of peroxisomes in cultured Leydig cells: a decrease in testosterone secretion precedes reduction of peroxisomes. Eur J Histochem 1995; 39:27380.

Bilinska B, Genissel C, Carreau S. Paracrine effects of seminiferous tubules factors on rat Leydig cell testosterone production: role of cytoskeleton. Biol Cell 1997;89:435-42.

Bilinska B, Kmicikiewicz I, Sadowska J, Piersiniski A. The effect of testicular macrophages, macrophage-conditioned medium and interleukin $-\alpha$ on bank vole Leydig cell cytoskeleton. Exp Clin Endocrinol Diab 1999;107:281-7.

Cao L, Leers-Sucheta S, Azhar S. Aging alters the functional expression of enzymatic and non-enzymatic anti-oxidant defense systems in testicular rat Leydig cells. J Steroid Biochem Mol Biol 2004; 88:61-7.

Carreau S. Paracrine control of human Leydig cell and Sertoli cell functions. Folia Histochem Cytobiol 1996;34:111-9.

Chemes HE. Leydig cell development in humans. In: Payne A, Hardy MP, Russell LD, eds. The Leydig cell. Cache River Press, Vienna, IL, 1996; 175-202.

Chemes H, Cigorraga S, Bergada C, Schteingart H, Rey R, Pellizzari E. Isolation of human Leydig cell mesenchymal precursors from patients with the androgen insensitivity syndrome: testosterone production and response to human chorionic gonadotropin stimulation in culture. Biol Reprod 1992;46:793-801.

Chen $H$, Luo L, Zirkin BR. Leydig cell structure and function during aging. In: Payne $A$, Hardy MP, Russell LD, eds. The Leydig cell. Cache River Press Vienna IL 1996;222-6.

Cooke BA. Transduction of the luteinizing hormone signal within the Leydig cell. In: Payne A, Hardy MP, Russell LD, eds. The Leydig cell. Cache River Press, Vienna, IL, 1996. pp. 351-64.

Ewing LL, Zirkin BR. Leydig cell structure and steroidogenic function. Rec Prog Horm Res 1983;39: 599-635.

Haider SG. Cell biology of Leydig cells in the testis. Int Rev Cytol 2004;233:181-241.
Hammar M, Petersson F. Testosterone production in vitro in human testicular tissue. Andrologia 1986;18:196-200.

Klinefelter GR, Ewing LL. Maintenance of testosterone production by purified adult rat Leydig cells for 3 days in vitro. In Vitro Cell Dev Biol 1989;25:283-8.

Kopera I, Tuz R, Kotula-Balak M, Schwarz T, Koczanowski J, Bilinska B. Morphofunctional alterations in testicular cells of deslorelintreated boars: an immunohistochemical study. J Exp Zool 2008; 309A:117-26.

Kotula M, Koziel E, Sadowska J, Gancarczyk M, Bilinska B. Immunofluorescent localization of the StAR protein in the mitochondria of mouse Leydig cells in vitro. Folia Histochem Cytobiol 2001;39:169-70.

Kotula-Balak M, Bablok L, Fràcki S, Jankowska A, Bilinska B. Immunoexpression of androgen receptors and aromatase in testes of patient with Klinefelter's syndrome. Folia Histochem Cytobiol 2004a;142:215-20.

Kotula-Balak M, Grzmil P, Styrna J, Bilinska B.-Immunodetection of aromatase in mice with a partial deletion in the long arm of the $Y$ chromosome. Acta histochem 2004b; 106:55-64.

Kotula-Balak M, Gancarczyk M, Sadowska J, Bilinska B. The expression of estrogen receptors $\alpha$ and $\beta$ in mouse Leydig cells in vitro that derived from cryptorchid males. Eur J Histochem 2005;49:395402.

Kotula-Balak M, Lenartowicz M, Kowal M, Styrna J, Bilinska B. Testicular morphology and expression of aromatase in testes of mice with the mosaic mutation (Atp 7-mo-ms). Theriogenology 2007;67:423-34.

Lejeune H, Sanchez P, Saez JM. Enhancement of long-term testosterone secretion and steroidogenic enzyme expression in human Leydig cells by co-culture with human Sertoli cell-enriched preparations. Int J Androl 1998;21:129-40.

Luo L, Chen H, Zirkin BR. Are Leydig cell steroidogenic enzymes differentially regulated during aging? J Androl 1996;17:509-15.

Maillard N, Wolczynski S, Argyriou A, Drosdowsky MA, Foucault P, Carreau S. Steroidogenesis in the two enriched-Leydig cell populations of human testis: evidence for a positive control by seminiferous tubules secreted factor(s). Arch Androl 1994;33:187-99.

Makabe S, Naguro T, Heyn R, Motta PM. Ultrastructure of human Leydig cells at early gonadal embryogenesis. It J Anat Embryol 1995; 100:525-33.

Mather JP, Saez JM, Haour F. Primary cultures of Leydig cells from rat, mouse and pig: Advantages of porcine cells for the study of gonadotropin regulation of Leydig cell function. Steroids 1981;38:35-44.

Mendis-Handagama SM LC, Watkins PA, Gelber SJ, Scallen TJ. Leydig cell peroxisomes and sterol carrier protein-2luteinizing hormonedeprived rats. Endocrinology 1992;131:2839-45.

Middendorff R, Davidoff M, Holstein AF. Neuroendocrine marker substances in human Leydig cells-changes by disturbances of testicular function. Andrologia 1993;25:257-62.

Middendorff R, Davidoff M, Mayer B, Holstein AF. Neuroendocrine characteristics of human Leydig cell tumours. Andrologia 1995;27:351-5.

Nistal M, Paniagua R, Regadera J, Santamaria L, Amat P. A quantitative morphological study of human Leydig cells from birth to adulthood. Cell Tissue Res 1986a;246:229-36.

Nistal M, Santamaria L, Paniagua R, Regadera J, Codesal J. Multinucleate Leydig cells in normal human testes. Andrologia 1986b;18:268-72.

Payne $A, 0^{\prime}$ Shaughnessy. Structure, function and regulation of steroidogenic enzymes in the Leydig cell. In: Payne A, Hardy MP, Russell LD, eds. The Leydig cell. Cache River Press, Vienna, IL, 1996;258-86.

Peltola V, Huhtaniemi I, Metsa-Ketela T, Ahotupa M. Induction of lipid peroxidation during steroidogenesis in the rat testis. Endocrinology 1996;137:105-12

Preslock JP. A review of in vitro testicular steroidogenesis in rodents, monkeys and humans. J Steroid Biochem 1980;13:965-75.

Prince FP. Ultrastructural evidence of mature Leydig cells and Leydig cell regression in the neonatal human testis. Anat Record 1990; 228:405-17. 
Prince FP. Mitochondrial cristae diversity in human Leydig cells: a revised look at cristae morphology in these steroid-producing cells. Anat Record 1999;254:534-41.

Purvis K, Clausen OPF, Hansson V. Regulation of Leydig cell sensitivity and responsiveness to LH/hCG. Int J Androl 1978;1:247-63.

Ramadoss S, Sivaraman PB, Narayanasami M-B; Jainul-Abideen IM, Perumal K, Karundevi B. Radiation exposure impairs luteinizing hormone signal transduction and steroidogenesis in cultured human Leydig cells. Toxicol Sci 2006;91:550-6.

Rivarola MA, Belgorosky A, Berensztein E, de Davila MTG. Human prepubertal testicular cells in culture: steroidogenic capacity, paracrine and hormone control. J Steroid Biochem Molec Biol 1995; 53:119-25.

Rommerts FFG. Testosterone: an overview of biosynthesis, transport, metabolism and ction. In: Nieschlag $\mathrm{E}$, Behre HM, eds. Testosterone: action, deficiency, substitution. Springer-Verlag, Berlin, Heidelberg, New York, London, Paris, Tokyo, Hong Kong, Barcelona 1981; 1-22.

Schulze C. Sertoli cells and Leydig cells in man. Adv Anat Embryol Cell Biol 1984;88:1-104.

Simpson BJ, Wu FC, Sharpe RM. Isolation of human Leydig cells which are highly responsive to human chorionic gonadotropin. J Clin Endocrinol Metab 1987;65:415-22.

Stocco DM, Wells J, Clark BJ. The effects of hydrogen peroxide on steroidogenesis in mouse Leydig tumor cells. Endocrinology 1993; 33: 2827-32.

Svechnikov KV, Sultana T, Söder 0. Age-dependent stimulation of Leydig cell steroidogenesis by interleukin-1 isoforms. Mol Cell Endocrinol 2001; 182:193-201.

Zirkin BR, Chen H, Luo L. Leydig cell steroidogenesis in aging rats. Exp Gerontol 1997;32:529-37. 